\title{
A Survey of the Effect of Social Media Marketing on Online Shopping of Customers by Mediating Variables
}

\author{
Alireza Mohammadpour ${ }^{1}$, Taher Roshandel Arbatani'2, Tahmoures Hassan Gholipour ${ }^{3}$, \\ Fereshteh Farzianpour ${ }^{4}$, Shadi Hosseini1 \\ ${ }^{1}$ Department of Management, University of Tehran Kish International Campus, Tehran, Iran \\ ${ }^{2}$ Department of Media Management, Tehran University, Tehran, Iran \\ ${ }^{3}$ Department of Management, Tehran University, Tehran, Iran \\ ${ }^{4}$ Department of Health Management and Economics, School of Public Health, Tehran University of Medical \\ Sciences, Tehran, Iran \\ Email: mohammadpour.ar@ut.ac.ir, ${ }^{*}$ farzianp@sina.tums.ac.ir, ${ }^{*}$ farzianp2@yahoo.com
}

Received 7 September 2014; revised 2 October 2014; accepted 25 October 2014

Copyright (C) 2014 by authors and Scientific Research Publishing Inc.

This work is licensed under the Creative Commons Attribution International License (CC BY).

http://creativecommons.org/licenses/by/4.0/

(c) (i) Open Access

\begin{abstract}
The present study aimed to evaluate the effect of social media marketing on online shopping of customers based on mediating role of value capital, relational capital and brand capital by path analysis method. 169 students of Tehran University were included in this study. They filled out the questionnaires of social media marketing, value capital, relational capital, brand capital and eshopping of customers. The results of path analysis showed that social media marketing had positive and significant impact on value capital, relational capital and brand capital. The direct effect of relational capital on value capital and brand capital was direct, positive and significant. Three variables of value capital, relational capital and brand capital had a direct and positive and significant effect on e-shopping of customers. Social media marketing had indirectly positive and significant impact on e-shopping of customers via value capital, relational capital and brand capital. Relational capital by value and brand capital had indirect, positive and significant impact on e-shopping of customers. Generally, the results of the present study supported mediating role value capital, relational capital and brand capital variables in relationship between social media and eshopping of customers.
\end{abstract}

\section{Keywords}

Brand Capital, E-Shopping Behavior, Relational Capital, Social Media Marketing, Value Capital

\footnotetext{
${ }^{*}$ Corresponding author.
}

How to cite this paper: Mohammadpour, A., et al. (2014) A Survey of the Effect of Social Media Marketing on Online Shopping of Customers by Mediating Variables. Journal of Service Science and Management, 7, 368-376. 


\section{Introduction}

Today, e-commerce is one of the important issues in business. E-commerce improves communication and open economy at national and international level, changing business method and changing traditional markets to its new forms. One of the new purchase methods with great advantages is e-shopping. Now, the majority of transactions are done by this method all over the world. According to the findings of the studies, more than half of pioneer companies' income is via electronic selling of their products [1] [2]. The benefits of usage of customers of e-shopping are based on developing the business, increasing sale and income, reduction of costs, indirect relationship between buyer and seller, increasing speed of affairs, reduction of costs of advertisement, relationship with customer or other tradesmen and it is provided at any time or place [3] [4]. Despite the researches in identification of effective factors on deciding to use e-shopping of cognitive, attitude and value variables, the questions increasing the decisions of customers to e-shopping are not answered completely [5] [6]. The identification of effective variable on decision of customers to use e-shopping is important for many organizations as it provides the opportunity of reducing the costs and increasing profit and it is effective on many performance fields in organizations. Social media marketing as a developing phenomenon plays an important role in the tendency of e-shopping of customers. Also, there are a few studies regarding the effect of social media marketing on eshopping of customers. The other important factor of this study is the evaluation of mediating role of value capital, relational capital and brand capital and this is less emphasized in any study. On the other hand, despite the increasing development of using internet in Iran, e-commerce and e-shopping are not common yet. People are not anxious to buy the products and services via internet of organizations facilitating this process [7] [8]. On the other hand, social media marketing is a new phenomenon playing important role in products or services marketing of companies and it improves the tendency of customers to purchase [9] [10]. Social media are those available easily and they lead to communication development. This advantage causes that the companies and organizations apply it to introduce their products and goods and affect the attitude of people to use e-shopping. The main question of the present study is whether value capital, relational capital and brand capital play a mediating role in relationship between social media marketing and customers' decision to use e-shopping?

\subsection{Theoretical Basics}

According to Keller (2001), "Marketing relation is a tool by which the companies can inform, motivate, stimulate and recall the consumers regarding their brands as directly and indirectly. Marketing relations enable the organizations to discuss with their consumers and they can advertise their brand by this relationship [11]. There are various types of marketing relation methods as all forms of advertisement, activities in public relations, marketing and personal selling [11]. O'Shea \& Alonso (2011) referred to websites, blogs, face book and tweeter as new tools of marketing relation by which the organizations can communicate with fans and stockholders.

E-shopping: In 21th century, a revolution is seen in people purchase. New technologies as internet, web, digital TV and video telephones made going to the stores as unnecessary process. Electronic access is developed and trading is easier and rapid without physical limitation [12]. Online trading is composed of three important components as information retrieving, information transfer and product purchase. Online trading has three different features compared to traditional trading. These three features include:

1) It applies extended technology;

2) Uncertainty, temporary and non-personal features of transaction in on-line space;

3) Explicit trading, unpredictability of technological equipment in trading and on-line transfer [13].

Thus, from specific nature of internet, inclination to purchase depends upon accepting E-commerce and customer evaluation of website of the company and it is important in customer decision making and purchase experience [14]. In an investigation, the effective factors on high tendency to e-shopping are introduced in three fields of customer, marketing and technological factors [15].

Social media is applied programs, platforms and on-line media (internet) with the aim of facilitating the interactions, collaboration and content sharing [9] [16]. These Medias have various forms including weblogs, social blogs, micro blogs, Wikis, podcasts, video images, photo, grading and collecting addresses and sites. Based on their considerable usage, not only the present individual users of social networks but also the commercial companies and state organizations join this group and use these facilities as their communication tools [9]. Based on the evidences [17] showed that social media are important for B2B companies. Indeed, B2B companies can use social media namely social network sites including Facebook and linkedin to communicate with customers and 
the suppliers, establishing trust and identification of future partners in terms of selling B2B [17]. Relational capital is the tendency of consumers to resort to a brand and its objective and subjective evaluations [18] [19]. Value capital is referred as objective evaluation of customer of brand desirability based on the perception of the observations [20].

Brand equity refers to the inherent and high value of a brand. Brand equity is created when the customers pay more for similar level of brand quality based on the fame of brand and belonging to it [21]. Final value of brand equity is the difference of the product value with brand and the product with the same quality and features but without any brand [1].

\subsection{Review of Literature}

Following Angella and Eunju (2012), do social media marketing activities enhance customer equity? An empirical study of luxury fashion brand, the results of the study showed that five constructs of perceived SMM activities as entertainment, interaction, trendiness, customization, and word of mouth had significantly positive impact on value equity, relationship equity, and brand equity. For the relationship between customer equity drivers and customer equity, brand equity had a significant negative effect on customer equity [9].

Vries et al., (2012) in a study Popularity of Brand Posts on Brand Fan Pages: "An Investigation of the Effects of Social Media Marketing", showed that positioning the brand post on top of the brand fan page enhances brand post popularity. But the findings also indicate that different drivers influence the number of likes and the number of comments. Namely, vivid and interactive brand post characteristics enhance the number of likes [22].

Michaelidou et al., (2011) "Usage, barriers and measurement of social media marketing: an exploratory investigation of small and medium B2B brands” showed that over 1/4 of B2B SMEs in the UK are currently using SNS to achieve brand objectives, the most popular of which is to attract new customers. On the other hand, the most significant barrier is the lack of perceived relevance for particular sectors [17].

Shih (2004) based on technology acceptance model considered the effect of variables of easy use, customers' satisfaction, usefulness of use and security of web on tendency to e-shopping [23]. He showed that by increasing customers' perceived ease of use, perceived usefulness and customers' satisfaction web security, individual attitudes toward e-shopping is increased [23]. Chung G. J., Lee S. H. (2008) investigated the effect of effective variables on online shopping [5]. Their findings showed that perception of website security, protecting private aspects of people and production innovation can have positive influence on online purchase [5].

Ha \& Stoel (2009) in a study investigated the effective factors on accepting e-shopping. Their results showed that e-shopping quality affects trust, easy use and customers' satisfaction of e-shopping. In addition, usefulness of use and positive attitude of customers, affects their decision to e-shopping positively [24].

Akbari and Hassangholipour (2002) in a study investigated the effective factors on acceptance of Tehrani customers of e-shopping system of Shahrvand store [25]. Their results showed that accepting to purchase from electronic stores of Shahrvand is dependent upon some factors as access of customers to internet, their awareness of electronic store, its free delivery, the attractions and capabilities of Shahrvand internet basis to respond the customers' demands and strong delivery system of this store are the important factors [25].

Olfat et al., (2011) in a study investigated the effective factors on e-shopping and their prioritization. The results of the study showed that purchase risk index is the most important factor in e-shopping and consumers consider e-shopping useful and they trust it [26].

Sanayei et al., (2010) in a study evaluated the effective factors on online buyers trust and its effect on eshopping intention. This study was done by an attitude evaluation by web-based questionnaire of the customers of internet book stores of Isfahan province [7]. The results of the study showed that trust had a direct effect on customer purchase intention of internet stores and security, internet offenses, web-space control, graphic appearance and website structure were effective on trust.

Sanayei et al., (2010) evaluated the effective factors on e-shopping. The results of their study showed that the most important factors on e-shopping are attitude to e-shopping, perception of usefulness of shopping at home, interaction speed and response time, privacy and two variables of social benefits and website design had no significant effect on trust in e-shopping [7].

\section{Study Method and Data Collection}

The present study is descriptive (Indices of the descriptive statistics for the example mean, standard deviation, 
minimum and maximum scores for the variables examined in this study is indicated in Table 1).

For data collection regarding theoretical basics and review of literature, library studies, required articles and books were used. For data collection and analysis, a questionnaire was used composed of general questions as general information and demographic questions of respondents and specialized questions as 36 items based on 5-item Likert scale as strongly disagree (1) to strongly agree (5). The identification of effective variable on decision of customers to use e-shopping is important for travel agency companies. In this research Social media marketing as a developing phenomenon plays an important role in the tendency of e-shopping of customers. Also, there are a few studies regarding the effect of social media marketing on e-shopping of customers. The other important factor of this study is the evaluation of mediating role of value capital, relational capital and brand capital and this is less emphasized in any study.

\subsection{Study Population and Sample}

The study population is the people who got familiar with different services of travel agency companies via social media as Twitter, FaceBook, Cloob, and Google Plus. The study population is 169 students of Tehran University and they are selected by purposeful sampling method in 2013.

\subsection{Conceptual Model of the Study}

Based on the models presented regarding the study subject, the present conceptual model is presented. In conceptual model, social media marketing is effective directly on value capital, relational capital and brand capital. Value capital, relational capital and brand capital directly affect intention to e-shopping. The study conceptual model is shown in Figure 1.

The hypotheses of the study are including:

1) Social media marketing has a positive effect on relational capital;

2) Social media marketing has a positive effect on brand capital;

3) Social media marketing has a positive effect on value capital.

\section{Table 1. Statistics of the collected data.}

\begin{tabular}{|c|c|c|c|c|}
\hline Variables & Mean & $\mathrm{SD}$ & Lower score & Highest score \\
\hline Social media marketing & 31.10 & 5.56 & 15 & 45 \\
\hline Value capital & 25.14 & 3.84 & 12 & 35 \\
\hline Relational capital & 25.25 & 5.47 & 10 & 39 \\
\hline Brand capital & 16.08 & 4.25 & 5 & 25 \\
\hline Intention to e-shopping & 15.08 & 3.01 & 4 & 20 \\
\hline
\end{tabular}

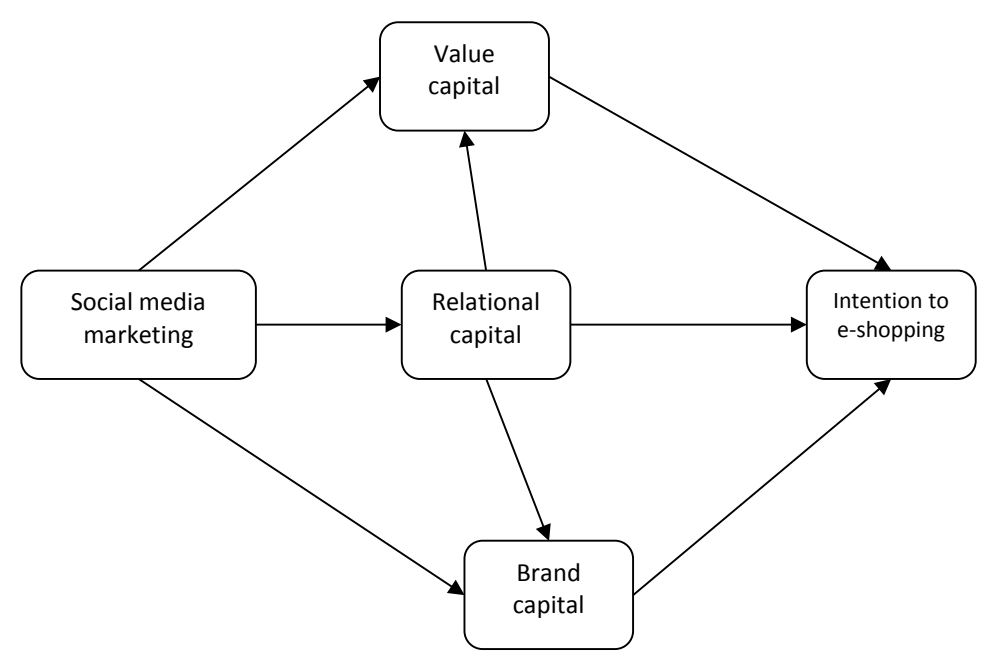

Figure 1. Conceptual model of study. 
4) Relational capital has a positive effect on intention to e-shopping;

5) Relational capital has a positive effect on value capital;

6) Relational capital has a positive effect on brand capital;

7) Value capital has a positive effect on intention to e-shopping;

8) Brand capital has a positive effect on intention to e-shopping.

Content validity is used to support the validity of the questionnaire. Cronbach's alpha is applied to determine reliability.

\subsection{Measures}

To measure social media marketing, the questionnaire of Kim and Ko (2012) was applied including 11 questions. The reliability of this instrument is 0.82 by Cronbach's alpha. To measure value capital, the questionnaire of Rust et al., (2004) and Vogel et al., (2008) was used with 7 questions and the Cronbach's alpha is 0.73. To measure value capital, the questionnaires Rust et al., (2004) and Vogel et al., (2008) were applied with 9 items and Cronbach's alpha was 0.86. To measure brand capital, Yoo and Donthu (2001) and Buil and Eva (2013) measures are used. This measure is composed of 5 items. The reliability of this instrument is 0.86 by Cronbach's alpha. Ardam et al., (2006) and Bill and Ava (2013) questionnaires were used. This measure is composed of 4 questions and it is 0.87 by Cronbach's alpha [1].

\section{Study Results}

In terms of respondents age, $49.7 \%$ are 20 to 25 years old, $35.5 \%$ are 26 to 30 years old, $13 \%$ are 31 to 35 years old and about $1.8 \%$ of respondents are above 36 years old. In terms of gender, $54 \%$ of respondents are men and the remaining are women. In terms of education, the highest frequency is about MA (63.3\%), BA (26.6\%), PHD (5.3\%), Associate (4.1\%) and Diploma (0.6\%). In terms of the experience of using the services of travel agency companies, the highest frequency is regarding the respondents with 2 to 3 years of using services (51.48\%), 1 to 2 years (18.93\%), 3 to 4 years (14.20\%), 4 to 5 years (10.06\%) and above 5 years (5.32\%). In terms of dedicating time in electronic social media per day, $40.8 \%$ respondents dedicated 1 to 2 hours of their time in electronic social media.

\subsection{Correlation Coefficient of Variables}

After determining the validity of measures, the identification of the relation between variables is the next step to enter the issue of path analysis. To identify the relationship between present variables, Pearson correlation coefficient is used. The results of correlation coefficient between study variables are shown in Table 2 . The results showed that correlation coefficient of intention to e-shopping had significant association with social media marketing $(r=0.39)$, value capital $(r=0.48)$, relational capital $(r=0.50)$ and brand capital $(r=0.49)$ at the level $P<$ 0.01 and the relation is positive. In addition, relational capital has positively significant association with brand capital $(\mathrm{r}=0.62)$ and value capital $(\mathrm{r}=0.59)$. The correlation coefficient of value capital and brand capital $(\mathrm{r}=$ $0.45)$ is positively significant.

\subsection{The Results of Path Analysis}

Figure 2 shows tested model with standardized values on each of paths. The results showed that path coefficients are significant and have a positive effect on each other. Also, the fitted indices for the tested model showed that RMSEA index in the estimated model is acceptable with value 0.036 and other fitting index as CFI, GFI, NFI, NNFI and AGFI at 1, 0.99, 0.98, 0.99, 0.96 are at suitable level and these goodness of fit show that the data of the study have good fitting with factor structure of this model.

The coefficients of direct, indirect, total effects coefficient and determined variance of study variables are shown in Table 3. The numbers outside of parenthesis and the numbers inside parenthesis are $t$ values of coefficients. In other word Parameter estimates are significant at the 0.05 level if the $t$ value exceeds 1.96 and at the 0.01 level if the t value exceeds 2.56. $t$ scores of path coefficients in Table 3 are higher than 1.96 therefore we cloud conclude that all coefficients are significant. In structural equation model it is not possible to examine the effect of an exogenous variable on two or more indigenous variable at the same time. But this method could examine the indirect effect of a variable on only the other variables though some other variables which indicated 
Table 2. Correlation matrix of study constructs.

\begin{tabular}{|c|c|c|c|c|c|c|}
\hline No. & Variables & 1 & 2 & 3 & 4 & 5 \\
\hline 1 & Social media marketing & 1 & & & & \\
\hline 2 & Value capital & $0.45^{* *}$ & 1 & & & \\
\hline 3 & Relational capital & $0.47^{* *}$ & $0.59^{* *}$ & 1 & & \\
\hline 4 & Brand capital & $0.37^{* *}$ & $0.45^{* *}$ & $0.62^{* *}$ & 1 & \\
\hline 5 & Intention to e-shopping & $0.39^{* *}$ & $0.48^{* *}$ & $0.50^{* *}$ & $0.49^{* *}$ & 1 \\
\hline
\end{tabular}

Table 3. The results of direct, indirect and total effects coefficients.

\begin{tabular}{|c|c|c|c|c|}
\hline Paths & Direct effect & Indirect effect & Total effect & Determined variance \\
\hline \multicolumn{5}{|c|}{ On intention to e-shopping from } \\
\hline Brand capital & $0.26^{* *}(3.23)$ & - & $0.26^{* *}$ & \multirow{4}{*}{$34 \%$} \\
\hline Value capital & $0.25^{* *}(3.24)$ & - & $0.25^{* *}$ & \\
\hline Relational capital & $0.19^{*}(2.12)$ & $0.270^{* *}(4.24)$ & $0.46^{* *}(6.74)$ & \\
\hline Social media marketing & - & $0.30^{* *}(5.99)$ & $0.30^{* *}$ & \\
\hline \multicolumn{5}{|l|}{ On brand capital from } \\
\hline Relational capital & $0.57^{* *}(8.25)$ & - & $0.57^{* *}$ & \multirow[t]{2}{*}{$39 \%$} \\
\hline Social media marketing & $0.11^{*}(2.06)$ & $0.27^{* *}(5.34)$ & $0.38^{* *}(5.26)$ & \\
\hline \multicolumn{5}{|l|}{ On value capital from } \\
\hline Relational capital & $0.48^{* *}(6.92)$ & - & $0.48^{* *}$ & \multirow[t]{2}{*}{$38 \%$} \\
\hline Social media marketing & $0.23^{* *}(3.31)$ & $0.23^{* *}(4.93)$ & $0.46^{* *}(6.64)$ & \\
\hline \multicolumn{4}{|l|}{ On relational capital from } & \multirow{2}{*}{$23 \%$} \\
\hline Social media marketing & $0.47^{* *}(6.97)$ & - & $0.47^{* *}$ & \\
\hline
\end{tabular}

${ }^{*} \mathrm{p}<0.05 ;{ }^{* *} \mathrm{p}<0.01$.

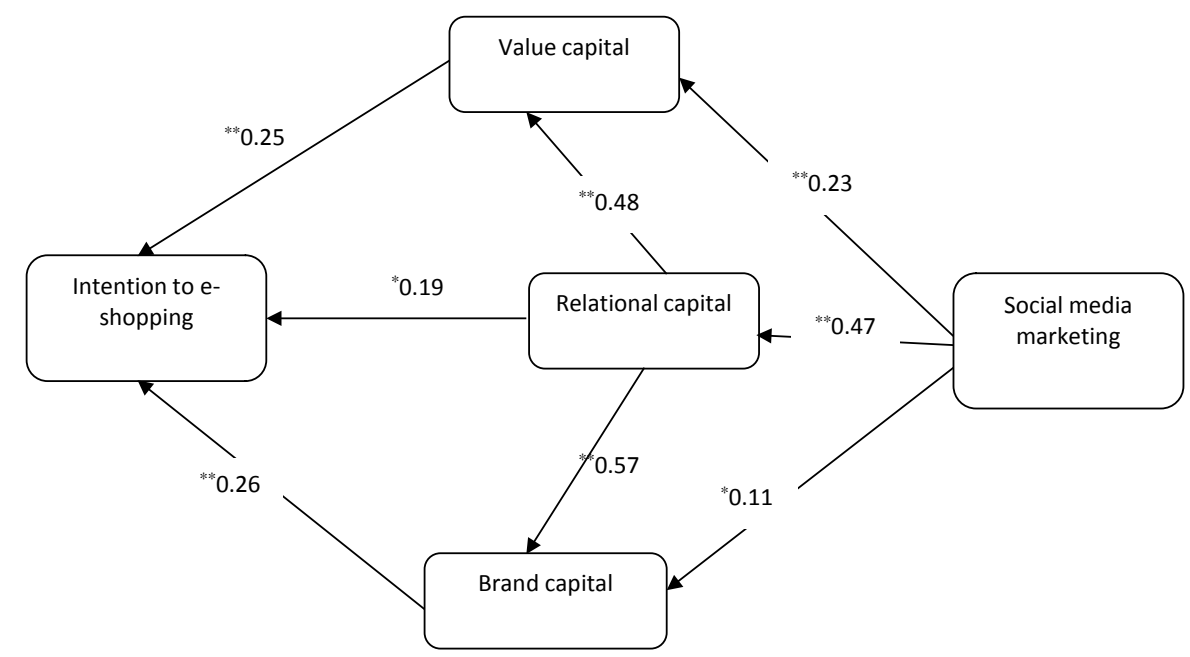

Figure 2. Tested model of study $\left({ }^{*} \mathrm{p}<0.05^{* *} \mathrm{p}<0.01\right)$.

in Table 3.

The fitting indices for the tested model in Table 4 showed that RMSEA index is acceptable in estimated model as 0.036 and other fitting indices as CFI, GFI, NFI, NNFI, AGFI are at suitable level with 1, 0.99, 0.98, $0.99,0.96$, respectively and the goodness of fit show that the data of the study have good fitting with the factor structure of this model. 
Table 4. The features of fitting of fitted model.

\begin{tabular}{ccccccc}
\hline AGFI & NFI & NNFI & GFI & CFI & RMSEA & x/df \\
\hline 0.96 & 0.98 & 0.99 & 0.99 & 1 & 0.036 & 1.21 \\
\hline
\end{tabular}

\section{Discussion and Conclusions}

First hypothesis of the study showed that SMM had a positive effect on relational capital. The results showed that SMM had a positive and significant effect on relational capital. This result is in line with the study of Kim and Ko (2012). Social media leads to friendly relations among people via the relations between the customers of a company and relational capital of company is increased. Indeed, via the interactions in social media among people, many values are exchanged among people and this leads to much information exchange among people, groups and companies. Thus, these relations created a trust and it is a valuable capital for organization. It can be concluded that the relationship between people and groups via social media and providing the information of travel agency companies leads to assurance, attachment and excitation to company and also it leads to much tendency of people to relation with company and they enjoy the relation. The second hypothesis of the study showed that SMM has a positive effect on brand capital. The results of the study supported this hypothesis and this is in line with the study of Kim and Ko (2012). This result showed that awareness of services and products of company increases brand capital of travel agency companies via social media, interesting items of social media in relation to brand for customers, providing information sharing, and transferring beliefs, updating information regarding the company services and searching the customized information regarding company services. Also, in case of similar technical features and the price of other brands, customers prefer to buy the services of that brand. It can be said that brand capital is closely associated with brand selection and it can facilitate decision-making process of consumer and activate brand purchase.

Third hypothesis of the study showed that SMM had a positive impact on value capital. The results supported this hypothesis. In other words, SMM leads to the increase of value capital of company. This is in line with the study of Kim and Ko (2012). Based on this finding, when the company provides suitable services via social media for customers, it leads to easy access of customers to services and goods of company and there is a consistency between price and quality of services and it also increases the value of this company for customers and the customers intention to shopping is increased based on the value of this company to them. Fourth hypothesis of the study showed that relational capital had a positive effect on intention to e-shopping.

The results of path analysis model supported this hypothesis. It can be said when the services in travel agency are done on time and people have continual assurance, attachment and excitation to the company and they are also satisfied with the company performance, their intention to e-shopping is increased. Chen, Y. H., \& Barnes S. (2007) showed that relational capital was effective on consumers' behavior [13].

The results supported the fifth hypothesis regarding the positive impact of relational capital on value capital. This finding showed that when people have friendly relation with company and if they are satisfied with relationship with company and continue their relation, the value of company is increased and purchasing from company gets easier. Also, they give value to the propositions presented by company and they consider the services of company as valuable. They also consider the price presented from the company and the time and effort for purchasing the services of the company as low compared to the presented services and the above items increase the value of the company to the customers.

The sixth hypothesis of the study regarding the positive impact of relational capital on brand capital is supported. This finding shows that relational capital of company increases the tendency of customers to continue relationship with company and satisfaction of performance and services of company increase brand value to the customers and consumers. Chen, Y. H., \& Barnes S. (2007) believed that websites and internet branding are effective on transferring brand image and relationship with potential and actual customers of institutions. The results of the study supported seventh hypothesis of the study regarding the positive impact of value capital on intention to e-shopping. In other words, the higher the value capital of company is, the higher the intention to eshopping of the services of the company. This result is in line with the results of the study of Kim and Ko (2012). Based on this result, when the value of a product or service for consumers and customers is higher, it has a positive impact on consumers' purchase intention and it causes that people are intended to purchase the products of the company. According to Aakerview (1991), value capital creates value for customer via increasing assurance 
in decision-making for purchase and consumer satisfaction and information interpretation [27]. Kim and Hyun (2010) stated that if a brand has high equity, the target consumer has positive behavior to brand and pay high price for product and re-purchases it [27]. As it was said, the created value affects via social media on customer intention to e-shopping.

The eighth hypothesis of the study showed that brand capital had a positive effect on intention to e-shopping and the result of the study supports the hypothesis. This finding is in line with the results of the study of Kim and Ko (2012) and Huang et al., (2011). According to the results of the study of Huang et al., (2011), brand capital helps the customers and consumers to reduce trading costs. In addition, brand capital is an important source for participation in keeping the competitive advantages and achievements. Veioutsou (2009) stated that when the consumer follows a specific brand in his routine life to meet his demands, he tries to find a name to make him satisfied. It can be said that in case of increasing brand capital in travel agencies, customers' e-shopping intention of products and services of the companies is increased considerably [28].

Based on general evaluation of fitted model, the following results include:

Among mediating variables (value capital, relational capital and brand capital), brand capital had the highest direct and positive effect on intention to e-shopping of travel agency companies. In addition, independent variable of the study, SMM had the direct, positive and significant impact on three mediating variables: relational, value and brand capital. Also, among mediating variables, relational capital had the indirect, positive and significant effect on intention to e-shopping of travel agency companies. As SMM had no direct impact on intention to e-shopping and its indirect effect is via value, relational and brand capital, it can be said value, relational and brand capital play a mediating role in SMM and intention to e-shopping.

\section{Applied Recommendations}

1) The present study evaluated the direct and indirect role of some of the variables in e-shopping intention. Thus, it is recommended to the managers and authorities of travel agency to investigate the features of their company based on the variables and improve them and also improve the new services and products and increase e-shopping intention of customers.

2) The results of the study showed that SMM had positive impact on relational, brand and value capitals. Thus, based on the importance of SMM, it is proposed that the managers and authorities of travel agency companies focus on solutions of improving marketing via social media and develop it and increase the intention to e-shopping of customers of their services.

3) The results showed that relational, brand and value capital had positive impact on e-shopping intention. Thus, it is proposed to the authorities and managers of travel agency company to provide the high quality services to meet the customers' needs, control prices to improve company capitals and increase e-shopping intention.

4) Another result of the study showed that relational capital is effective on value capital and brand capital and purchase intention is also affected. Thus, it is proposed to the managers and authorities of travel agency companies to exchange information in their marketing in social media and create friendly relations among people and this leads to intention and excitation of people to continue to communicate with these companies.

\section{References}

[1] Kim, J.H. and Hyun, Y.J. (2010) A Model to Investigate the Influence of Marketing Mix Efforts and Corporate Image on Brand Equity in the IT Software Sector. Industrial Marketing Management, 40, 424-438.

[2] Farzianpour, F., Aghababa, S., Delgoshaei, B. and Haghgoo, M. (2011) Performance Evaluation a Teaching Hospital Affiliated to Tehran University of Medical Sciences Based on Baldrige Excellence Model. American Journal of Economics and Business Administration, 3, 272-276.

[3] Turban, E., McLean, E. and Wetherbe, J. (2002) Information Technology for Management. 3rd Edition, John Wiley \& Sons, New York. http://www.fishmart.com

[4] Farzianpour, F., Pishdar, M., Shakib, M.D., Hashemi, S. and Toloun, M.R. (2014) Consumers’ Perceived Risk and Its Effect on Adoption of Online Banking Services. American Journal of Applied Sciences, 11, 47-56. http://dx.doi.org/10.3844/ajassp.2014.47.56

[5] Chung, G.J. and Lee, S.H. (2008) Exploratory Research on Audiences’ Valuation Factors of Interactive TV Advertising: Applying Diffusion Theories. Journal of Korean Medical Science, 8, 261-286. 
[6] Farzianpour, F., Raheimi fouroshani, A., Mohamadi, A. and Hosseini, S.S. (2013) Evaluation of the Relationship between Social Capital and Manpower's Burnout in Teaching Hospitals of Iran. African Journal of Business Management, 7, 2872-2881. http://www.academicjournals.org/AJBM

[7] Ali, S., Ahmad, F. and Bahare, N. (2010) The Evaluation of Effective Factors on Online Customers Trust and Its Impact on E-Shopping Intention by Structural Equations Modeling. Proceedings of the 1st International Conference of Management and Innovation, USA, 44-51.

[8] Farzianpour, F., Rahimi Fouroshani, A., Vahidi, R.G.H., Arab, M. and Mohamadi, A. (2011) Investigating the Relationship between Organizational Social Capital and Service Quality in Teaching Hospitals. American Journal of Economics and Business Administration, 3, 425-429. http://dx.doi.org/10.3844/ajebasp.2011.425.429

[9] Kim, A.J. and Ko, E. (2012) Do Social Media Marketing Activities Enhance Customer Equity? An Empirical Study of Luxury Fashion Brand. Journal of Business Research, 65, 1480-1486. http://dx.doi.org/10.1016/j.jbusres.2011.10.014

[10] Pishdar, M., Toloun, M.R.S.H., Zamani, S. and Farzianpour, F. (2014) Development of Factors Effective in the Success of Green Supply Chain Management. American Journal of Agricultural and Biological Sciences, 9, 33-43.

[11] Keller, K.L. (2001) Strategic Brand Management: Best Practice Cases in Branding: Lessons from the World’s Strongest Brand. Pretice Hall, USA.

[12] Forushani, S., Mohammad, R. and Kuhgilani, N. (2004) Electronic Impact in the Early Third Millennium. Trading Publication Company of Trading Researches and Studies, Germany.

[13] Chen, Y.H. and Barnes, S. (2007) Initial Trust and Online Buyer Behavior. Industrial Management \& Data, 107, 4-8.

[14] So, W.C.M., Wong, T.N.D. and Sculli, D. (2005) Factors Affecting Intentions to Purchase via the Internet. Industrial Management \& Data Systems, 105, 1225-1244. http://dx.doi.org/10.1108/02635570510633275

[15] Kim, Y.H. (2004) A Study of Online Transaction Self-Efficacy Trust and Uncertainty Reduction in Electronic Commerce Transaction. Proceedings of the 38th Hawaii International Conference on System Sciences, Big Island, 3-6 January 2005, 11-24.

[16] Richter, A. and Koch, M. (2007) Social Software-Status quo und Zukunft. Technischer Bericht, Nr.-01, Fakultätfür Informatik. Universität der BundeswehrMünchen, Sweden.

[17] Michaelidou, N., Siamagka, N.T. and Christodoulides, G. (2011) Usage, Barriers and Measurement of Social Media Marketing: An Exploratory Investigation of Small and Medium B2B Brands. Industrial Marketing Management, 40, 1153-1159. http://dx.doi.org/10.1016/j.indmarman.2011.09.009

[18] Rust, R.T., Lemon, K.N. and Zeithaml, V.A. (2004) Return on Marketing: Using Customer-Equity to Focus Marketing Strategy. Journal of Marketing, 68, 109-127. http://dx.doi.org/10.1509/jmkg.68.1.109.24030

[19] Vogel, V., Evanschitzky, H. and Ramaseshan, B. (2008) Customer-Equity Drivers and Future Sales. Journal of Marketing, 72, 98-108. http://dx.doi.org/10.1509/jmkg.72.6.98

[20] Rust, R.T., Zeithaml, V.A. and Lemon, K.N. (2000) Driving Customer Equity. The Free Press, New York.

[21] Alivije, K. and Reza, M. (2011) The Design and Determination of the Model of Brand Equity Based on Performance on Brand Performance in Market (Case Study: Dairy Products Market of Tehran). Asadollah, Hushang. Shahid Beheshti University, Business Department, Iran.

[22] de Vries, L., Gensler, S. and Leeflang, P.S.H. (2012) Popularity of Brand Posts on Brand Fan Pages: An Investigation of the Effects of Social Media Marketing. Journal of Interactive Marketing, 26, 83-91. http://dx.doi.org/10.1016/j.intmar.2012.01.003

[23] Shih, H.-P. (2004) An Empirical Study on Predicting User Acceptance of E-Shopping on the Web. Information \& Management, 41, 351-368. http://dx.doi.org/10.1016/S0378-7206(03)00079-X

[24] Ha, S. and Stoel, L. (2009) Consumer E-Shopping Acceptance: Antecedents in a Technology Acceptance Model. Journal of Business Research, 62, 565-571. http://dx.doi.org/10.1016/j.jbusres.2008.06.016

[25] Akbari, M. and Hassangholipour, T. (2002) The Investigation of Effective Factors on Purchasing Electronic Stores of Shahrvand. Management Knowledge Journal, 4, 38-49.

[26] Olfat, L., Khosravani, F. and Jalali, R. (2011) The Identification of Effective Factors on E-Shopping and Their Prioritization by Fuzzy ANP. Business Management Journal, 3, 19-54.

[27] Aaker, D.A. (1991) Managing Brand Equity: Capitalizing on the Value of Brand Name. Free Press, New York.

[28] Veioutsou, C. (2009) Brand as Relationship Facilitations' in Consumer Markets. Journal of Marketing Theory, 9, 127130. http://dx.doi.org/10.1177/1470593108100068 
Scientific Research Publishing (SCIRP) is one of the largest Open Access journal publishers. It is currently publishing more than 200 open access, online, peer-reviewed journals covering a wide range of academic disciplines. SCIRP serves the worldwide academic communities and contributes to the progress and application of science with its publication.

Other selected journals from SCIRP are listed as below. Submit your manuscript to us via either submit@scirp.org or Online Submission Portal.
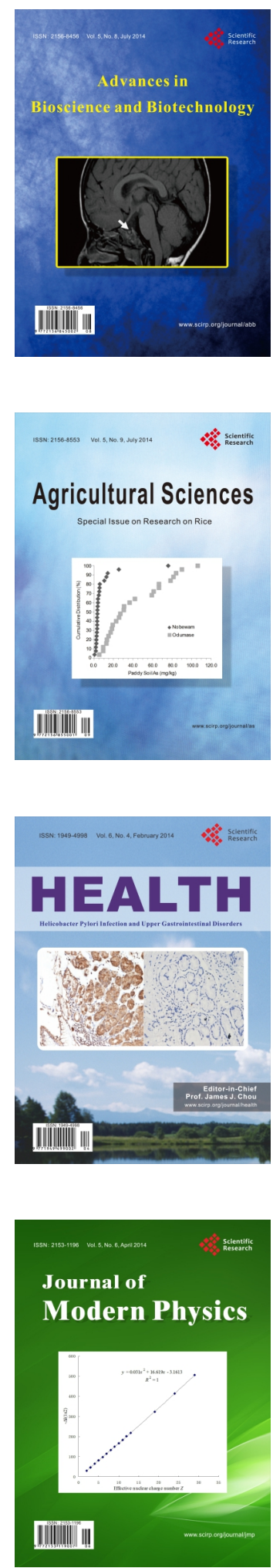
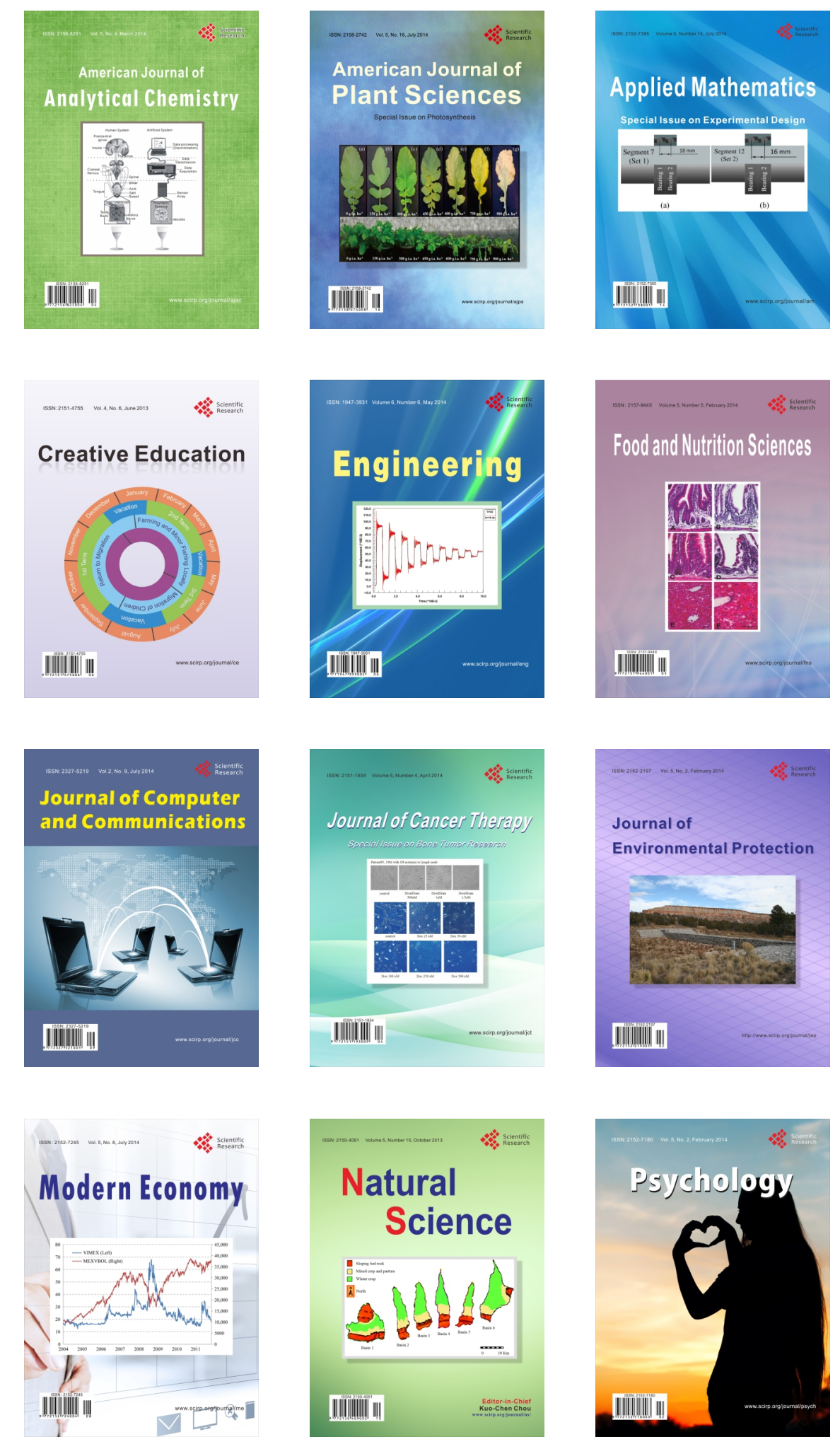